\title{
The authorised transcript of the score of Beethoven's Sixth Symphony in F major, opus 68
}

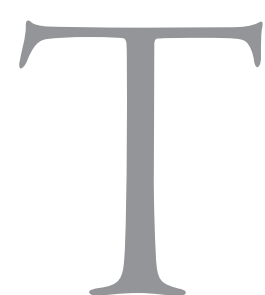

he authorised transcript of the score of Beethoven's Sixth Symphony in F major, op. 68, is one of the treasures of the National and University Library (NUK) in Ljubljana. Since coming into the library's possession, it has been exhibited several times, as well as studied and admired in the reading room of the Music Collection by eminent researchers and performers, experts about Beethoven's work, as well as other interested visitors. The paths of the manuscript before its coming to NUK, however, are more unclear and mysterious. Certain suppositions expressed in the past relating to its provenience are explained today, others omitted, but the most provoking ones are still awaiting confirmation, perhaps not yet found in veiled and widely dispersed written sources. The score was transcribed from Beethoven's autograph in the last quarter of 1808 and served for the first public performance of

I On $200^{\text {th }}$ anniversary of Beethoven's birth, the NUK Musical department prepared a Beethoven exhibition. Among other items, they exhibited the first prints published in the composer's lifetime, the oldest concert programmes with performances of Beethoven's compositions and material in relation to electing Beethoven the honorary member of the Ljubljana Philharmonic Society. the symphony in Vienna on 22 December $1808 .{ }^{2}$ It was transcribed by professional copyist Joseph Klumpar, with whom Beethoven had collaborated between 1805 and $1808 .^{3}$ The composer has additionally written the title to the score, added several instructions for play, and corrected a few notes.

The score was taken from the archive of Ljubljana Philharmonic Society in 1862 by its chronicler Friedrich Keesbacher (1831-190I) and first brought it to the attention of the public in a historical review of the society's activity, published in the supplement of Ljubljana paper Laibacher Zeitung. ${ }^{4}$ Keesbacher, a doctor by profession, had settled in Ljubljana

2 Jens Dufner, 'Kritischer Bericht', in Beethoven Werke, Abt. I, Bd. 3, Symphonien III, ed. Jens Dufner (München: G. Henle, 2013), 277.

3 Alan Tyson, 'Notes on five of Beethoven's Copyist', Journal of the American Musicological Society 23, no. 3 (1970): 456-60; Sieghard Brandenburg, ed., Ludwig van Beethoven - Briefwechsel Gesamtausgabe, I (München: G. Henle Verlag, 1996-1998), 327-8; Jens Dufner, 'Schreibdialoge. Beethoven und sein Kopist Joseph Klumpar', in Bonner Beethoven-Studien, Band II, edited by Bernhard R. Appel, Joanna Cobb Biermann, and Julia Ronge (Bonn: Beethoven-Haus Bonn, Carus, 20I4), 68

4 Friedrich Keesbacher, 'Die philharmonische Gesellschaft in Laibach, seit dem Jahre ihrer Gründung 1702, bis zu ihren letzten Umgestaltung I862. Eine geschichtliche Skizze,' Blätter aus Krain, October 18, 1862, 169-70, and in the offprint Friedrich Keesbacher, Die philharmonische Gesellschaft in Laibach 
only a year before, which is why he relied on oral accounts of contemporaries and the society archive. While examining the documents, he came across the Beethoven's forgotten letter of gratitude for the granting of honorary membership from 1819 and raised his eyebrows when reading it. Drawing his attention was the master's promise that he would send, at his earliest convenience to the society in thanks for his naming a yet unpublished work of his. The transcript of the Sixth Symphony, with a postscript 'Beethovens Hand mit Röthel', was the only one from among the society's musical sources that the great master could still have held in his hands. Even though Keesbacher concluded the paragraph on Beethoven's contacts with Ljubljana in meaningful words - 'be that as it may, in two words written in red, the society has, in either case, a dear memory of the great master of musical art, and it cannot be resented that it dares to assume to have received one of Beethoven's most important works in such an honourable way',- , the thought of having found the composition that the composer sent to the musicians in Ljubljana was too enticing to seriously want to doubt it. ${ }^{6}$

seit dem Jahre ihrer Gründung 1702 bis zu ihren letzten Umgestaltung I862. Eine geschichtliche Skizze (Laibach, 1862), 5I-2.

$5 \quad$ 'Sei dem aber wie ihm wolle, jedenfalls besitzt die Gesellschaft in den 2 mit Rothstift geschriebenen Worten ein liebes Andenken an den Großmeister der Tonkunst und man kann es derselben nicht verargen, wenn sie der Vermuthung Raum gibt, eines der bedeutendsten Werke Beethovens in so ehrender Weise erbalten zu haben.' Friedrich Keesbacher, 'Die philharmonische Gesellschaft in Laibach, seit dem Jahre ihrer Gründung 1702, bis zu ihren letzten Umgestaltung 1862. Eine geschichtliche Skizze,' Blätter aus Krain, October I8, I862, I70.

6 For the past seventy years, the researchers of the history of music in Slovenia have both agreed with and contradicted Keesbacher's assumption. Its argumentations have not been based on tangible sources, except in the articles of Ivan Klemenčič, who referred to comparative research made in an international frame in the I970s and I990s. (Ivan Klemenčič, 'Beethovna 6. simfonija in zveze z Ljubljano,' in Zbornik Narodne in univerzitetne knjižnice: II, edited by Branko Berčič, Jože Munda, Maks Veselko, and France Vurnik (Ljubljana: NUK, I978), 9I-9; Ivan Klemenčič, 'Šesta simfonija Ludwiga van Beethovna in njegove zveze z Ljubljano,' in Zbornik ob jubileju Jožeta Sivca, edited by
The score before us today testifies most convincingly on its former image, changes, and use. The format of the score is oblong, with a height, length and width of the binding of $22 \times 31.5 \times 2.4 \mathrm{~cm}$. The sheets measure about $21.3 \times 30 \mathrm{~cm}$. Cover width is $0.3 \mathrm{~cm}$. The spine is bent; on it are the impressions of three binding threads. The spine is bound in leather; the front and back hard millboard covers are coated with brown marble paper. On the front cover, there is a decoratively cut out label with the sign ' $\mathrm{N}^{\circ} \mathrm{I}$.', where the number ' $\mathrm{I}$ ' is crossed out and corrected to ' 6 ', and two round seals of the Philharmonic Society in Ljubljana ('Philharm. Gesellschaft in Laibach'). Bound in between the covers are the wrapper and 113 folios in five stitchings of differing extents, coinciding with the five movements of the symphony. The book block is sewn with a thread through the spine. The edges are sprayed with blue dots. The binding was partially restored in recent times (probably upon the exhibition at NUK in 1967 or 1970). Added or replaced were the capital band and the capital, and new binding sheets were glued on. Translucent Japanese paper was glued in between the wrapping and the cover, as well as between the pages $76-77,98-99$, and $184-185$. Pages were archivally numbered on recto (i.e., odd) pages, and the last written page, likely at inventorying and the bibliographical processing in the library. There are no traces of older pagination in the manuscript.

Several sorts of mechanically rastered music paper are present. The first three movements are written on a twelve-system paper. The staves are about $0.75 \mathrm{~cm}$ high and around $25.7 \mathrm{~cm}$ long. The distance between the top line of the first stave and the bottom line of the last stave is 18.5

Jurij Snoj and Darko Frelih (Ljubljana: Založba ZRC, ZRC SAZU, 200o), II9-30.) The discussion was also published in an English translation: Ivan Klemenčič, 'The Sixth Symphony by Ludwig van Beethoven and His Connections with Ljubljana,' in Glazbene kulture na Jadranu u razdoblju klasicizma: radovi s medunarodnog muzikoloskog skupa održanog u Dubrovniku, Hrvat ska, 24.-26.05.200I = Musical Cultures in the Adriatic Region Ruring the Age of Classicism: Proceedings of the International Musicological Symposium Held in Dubrovnik, Croatia, on May 24-26, 200I, edited by Vjera Katalinić and Stanislav Tuksar (Zagreb: Hrvatsko muzikološko društvo, 2004), 105-19. 


\begin{tabular}{|c|c|c|c|c|}
\hline Fol. & pg. & Content & Paper & Watermark \\
\hline Ir & I & title pg. & \multirow{4}{*}{ I2-row } & \multirow{4}{*}{$\begin{array}{l}\text { starfish }- \text { EGA - crescent moon with a face } \\
\left(\mathrm{I}^{\text {st }} \text { sheet of } 3^{\text {rd }} \text { movt.: three crescent moons }- \text { GFA }\right)\end{array}$} \\
\hline $\mathrm{IV}-38 \mathrm{~V}$ & $2-76$ & $\mathrm{I}^{\mathrm{st}}$ movt. & & \\
\hline $39 \mathrm{r}-55 \mathrm{~V}$ & 77-IIO & $2^{\text {nd }}$ movt. & & \\
\hline $56 \mathrm{r}-8 \mathrm{ov}$ & III-I60 & $3^{\mathrm{rd}}$ movt. & & \\
\hline $8 \mathrm{Ir}-92 \mathrm{~V}$ & I6I-I84 & $4^{\text {th }}$ movt. & I 4-row & IF - three crescent moons \\
\hline $93 r-113 v$ & $185-226$ & $5^{\text {th }}$ movt. & I4-row & eagle with raised wings - GFA - three crescent moons \\
\hline
\end{tabular}

$\mathrm{cm}$. The watermark is a six-armed starfish (height and width $2.8 \mathrm{~cm}$ ) above the letters EGA (width $8.5 \mathrm{~cm}$ ) and a crescent moon with a face (width $3.2 \mathrm{~cm}$ ). ${ }^{7}$ Already different to the touch are the first and the last sheets of the third movement with three crescent moons imprinted (width approximately $9 \mathrm{~cm}$ ) and the letters 'GFA' (width $6.5 \mathrm{~cm}$ ). The fourth and fifth movements are written on a fourteen-system paper. The staves of the fourth movement are about $0.7 \mathrm{~cm}$ high and $25.7 \mathrm{~cm}$ long. The distance between the top line of the first stave and the bottom line of the last stave is $18.6 \mathrm{~cm}$. The watermark on the paper are the letters 'IF' and three crescent moons (width approximately II $\mathrm{cm}$ ). The watermark on the paper of the fifth movement is an eagle with raised wings (width $5.5 \mathrm{~cm}$ ) above the letters 'GFA' (width $6.5 \mathrm{~cm}$ ) and three crescent moons (width approximately $8.5 \mathrm{~cm}$ ). The staves are around $0.65 \mathrm{~cm}$ high and about $25.7 \mathrm{~cm}$ long. The distance between the top line of the first stave and the bottom line of the last stave is $19.3 \mathrm{~cm}$.

Impressions in the paper show that the sheets of paper had been folded horizontally and vertically and cut through along the longer fold. The folded sheets obtained in this way, bifolios in oblong format, had been folded into one another according to the number of pages predict-

7 The sheets of paper are cut through in the middle of watermarks, so the height could not be measured.

ed for the transcript of the entire movement. The deviations point to changes in the transcribing process or to later replacements.

The first movement holds 19 upfolded sheets, stitched along the central fold with four disproportionately long stitches. Visible are traces of an older perforation (five incisions in distances of about $3.5 \mathrm{~cm}$ between the first and the second one, and around $5.5 \mathrm{~cm}$ between the following three). The second movement contains eight upfolded sheets, stitched along the middle of the spine. Between the $6^{\text {th }}$ and the $7^{\text {th }}$ sheets, there is an additional folio sewn in on the left side. The lengths of the stitches and traces of perforation are equal to or in the same proportions as those in the first movement. In the third movement, the sheets are folder much more complex than the preceding ones. Inserted into two outside bifolios are two bundles of sheets with five and four folded sheets, behind which another upfolded sheet is glued in. Both bundles are stitched in four disproportionately long stitches. Between the third and the fourth sheet of the second bundle, an additional folio is sewn-in on the left. There are traces of the original perforation visible in the second bundle. The fifth movement comprises io upfolded sheets, stitched along the middle of the spine in four stitches. Between the second and the third sheet, an additional folio is sewn-in (a part of the watermark with a lily points on the same sort of paper as the one used in the last 
two movements of Beethoven's autograph). ${ }^{8}$ In the right-side folios, three incisions are visible, approximately $5.5 \mathrm{~cm}$ apart from one another. The fourth movement holds six upfolded sheets, sewn in the middle in four darker stitches, and an additional longer, brighter stitch running through one half of the height of the page. On pages 165 and 168 , there are smaller particles, glued over with rastered paper and corrected.

In the bottom right corner of the final folios of the second, third, and fifth movements, a copyist's notation of the extent or the amount of sheets used, matching the sum of sheets in the stitching, is visible $\left(2^{\text {nd }}\right.$ movement: $81 \frac{1}{2} ; 3^{\text {rd }}$ movement: illegible; $5^{\text {th }}$ movement: ' $101 / 2$ ').

The manner of paper folding, the traces of incisions, and the yellowing of the outer sides of wrapping folios of individual movements prove that, initially, the score was not bound in a whole, but into separate stitchings. Especially pages I (title page), 77 (beginning of the $2^{\text {nd }}$ movement) and 185 (beginning of the $5^{\text {th }}$ movement) testify to a more intense exposure to light and other influences of the environment than neighbouring inner pages, whereas the bottom pages of upfolded sheets are also dirtier. An exception is the fourth movement, in which, except for the traces of leafing through in lower bottom corners of the pages, otherwise present in the entire score, there are no more explicit environment influences.

The manuscript is written in ink by the hand of Beethoven's copyist Klumpar, except for the fourth movement that was written by a thus-far unidentified copyist. Visible in several spots are supplements or corrections in graphite pencil, and also in red crayon in two places (Röthel). Thus, apart from the writing of the principal copyist, there are strokes of other hands present on the wrapping and the title page, as well as in the notation.

Written on the bound wrapping in unidentified older writing is: 'Symphonie pastorale'. Hemmed in a slim decorative curve is the title, under which the composer is stated: 'Beethoven'. Above the title, there

8 Sieghard Brandenburg, 'Kommentar,' in Ludwig van Beethoven. Sechste Symphonie F-Dur, Opus 68: Sinfonia pastorale. Faksimile nach dem Autograph BH 64 im Beethoven-Haus Bonn (Bonn: Beethoven-Haus, 2000), 10, $12-3$. is a twice crossed out (with hatches to the right and the left side), but clearly visible note: 'Ouverture'. Written in the same height, toward the right page margin, is the number ' $\mathrm{N}^{\circ}$ 6.', and toward the left one, a stamp of the Philharmonic Society.

On the title page, written in a heavily faded red pencil in Latin letters, is 'Sinfonia pastorale'. The beginnings of both words, written below one another, are somewhat covered over by two firmly drawn lines crossed in the middle. There are also two equally crossed red lines in the bottom half of the page. Under the inscription, someone added in German: 'Beethovens Hand mit Röthel'. The last inscription to the page was most likely added by the curator of the society's music archive, who had written on the top of the stave: 'Beethovens', 'Sinfonie pastorale', and further under the title ' $\mathrm{N}$ ' 6 .'

The score is arranged in the manner of Beethoven's autographs of the time. The strings are written down separately, violins and violas on top, and the cellos and contrabasses at the bottom of the score. In the first and the second movements, arranged in the same sequence as in the autograph, are the parts for first violins, second violins (violini), viola (viola), two flutes (flauti), two oboes (oboe), clarinet (clarinetti), basson (fagotti), two horns (corni), cellos (violoncelli) and contrabasses (bassi). In the second movement, the violins are playing with sordina (violini con sordini). In the third movement, eleven staves are filled, since Beethoven also positioned two trumpets (clarini) in front of the cellos. The score of the fifth movement, with the inclusion of two trombones set in front of the trumpets, comprises thirteen systems. The tuning of the clarinets (in $B)$ is written in the first movement, that of the horns $($ in $B)$ in the second one, and that of the trumpets (in $C$ ) in the third and the fifth movement. In the fourth movement, the arrangement of parts in the score deviates from the autograph, and their naming also differs. In the fourteen staves are the parts for first violins, second violins (violini), viola (viola), two flutes (flauti), two oboes (oboe), two clarinets (clarinetti in B), two bassons (fagotti), two horns (corny F), piccolo (picolo), two trombones (trombony), two trumpets (Trompe in Es), timpani (Timpani in C F), cellos (violoncello) and contrabasses (bassi). 
The copyist Klumpar had transcribed the score directly from the autograph. The proof of this is numbers added by his hand on the upper margin of Beethoven's manuscript that match the otherwise unnumbered pages of each of the transcript movements. Apart from this sequence of numbers, there is a partially blurred sequence of numbers visible in the autograph, matching the arrangement of pages of the copyist's first transcript of the score. It is undoubtedly a disposition of pages before the start of the transcribing, since the numbers are positioned on the bar line of the last bar in the range of a single page. The information on the number of pages served the preparation of the music paper.

Analysed in detail in the critical report by Jens Dufner to the edition of the symphony in Beethoven's complete works, based on the research of primary sources done in previous decades, are individual phases in the writing of the autograph, the transcribing of the score and instrumental parts, and the composer's interventions in the note records. ${ }^{9}$

The comparative analyses have shown that the copyist had been transcribing from the autograph three times. He had first, likely before June I808, worked out the instrumental parts for the already finished first three movements of the symphony. In the summer of 1808 , Beethoven finished the last two movements of the symphony, and the copyist transcribed the entire score by the middle of September for the publisher Gottfried Christoph Härtel. On this template, he also manufactured the parts for the final two movements. These supposedly served for rehearsals and private performances in the circle of Beethoven's patrons. ${ }^{1}$ The dynamic markings and some other completions that had been subsequently entered in the autograph and the parts' transcripts by either Beethoven or Klumpar were noted in the score transcript by an unidentified foreign hand. Beethoven had re-examined both the autograph and

9 Dufner, 'Kritischer Bericht,' 279-87; Brandenburg, 'Kommentar,' I8-28; Jonathan Del Mar, Ludwig van Beethoven. Symphonie Nr. 6 in F-Dur: Pastorale, op. 68. Critical commentary (Kassel etc.: Bärenreiter, 1998), I8-28; Shin Augustinus Kojima, 'Probleme im Notentext der Pastoralsymphonie op. 68 von Beethoven,' Beethoven-Jahrbuch o (1977): 223-43.

Io Brandenburg, 'Kommentar,' 22-3. the transcript, and wrote corrections and completions to both sources parallel in red chalk, while also correcting some obvious errors and inconsistencies in dynamic markings in the transcript. In mid-September the publisher Härtel carried the transcribed score in Leipzig, after which it was no longer accessible to Beethoven. Dufner finds that the evolutional path of the symphony begins to separate, since Beethoven did not consistently adjust the two scores (the autograph and the transcript) also due to their different purposes. The autograph had remained competent in Beethoven's examination of the orchestral parts and for the manufacturing of the performing score, while the transcript was the basis for the later print. Only after the score transcript had already been delivered to the publisher by Beethoven did he also enter in the original score the corrections and additions from the already played-through manuscript parts. This time, he was writing in pencil and partially in ink, and as a rule additionally marked his entries with a cross at the outside margin. It was mainly about marking precisely the dynamics and the articulation, completing performance instructions, but also the writing out of empty spots and correcting of errors. He had also made completions and corrections in the inverse direction.

The second transcript or the performing score kept in Ljubljana today, unlike the first one, which Beethoven had sold to the Leipzig publisher as a printing template, pays regard to all of Beethoven's adjustments and additions from the autograph, but not the corrections that Beethoven had exclusively added in the first transcript. Moreover, some errors and inconsistencies occurred by the hand of the copyist. Before the first public performance, Beethoven only corrected the transcribed score and parts. He had no longer entered the final corrections in the autograph; therefore, it seems that he had considered the second transcript of the original as the reference record of the work. On an empty first page, he wrote in red the title 'Sinfonia pastorale' for the first time. ${ }^{\mathrm{II}}$

II Today, all three manuscript scores are accessible online: Sinfonia 6 ta, autograph, [18०8], Beethoven-Haus Bonn, BH 64 and 6ta Sinfonia Pastorella, au-
313 
Beethoven's autographic corrections and additions in pencil

$2^{\text {nd }}$ movement

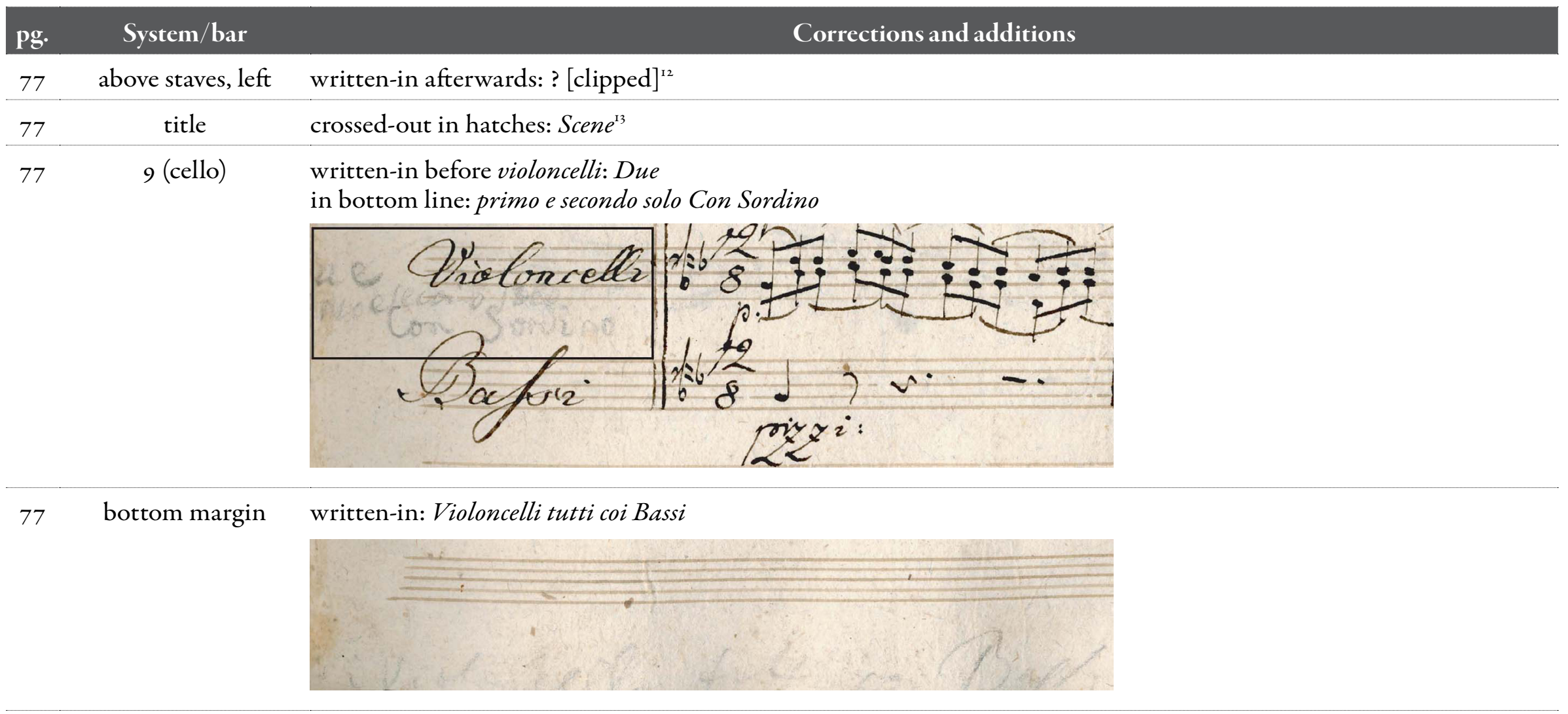

thorised transcript, [1808], Beethoven-Haus Bonn, NE 146 in Digitales Archiv at www.beethoven.de/de/digitales-archiv; Sinfonia pastorale, authorised transcript, [1808]. National and University Library, Ljubljana, Music Collection, M tre/and Beethoven (Inv. no. MZ 1765/1955) and Digital Library of Slovenia at www.dlib.si.

I2 Del Mar concluded from the bottom curve in pencil that the corrected tempo markin could have been »quasi allegro « (Jonathan Del Mar, Ludwig van Beethoven. Symphonie Nr. 6 in F-Dur: Pastorale, op. 68. Critical commentary (Kassel etc.: Bärenreiter, 1998), 35).

13 This is probably merely a correction of the copyist's transcript. 


\begin{tabular}{lll} 
Pg. & System/bar & number of bars: 20 \\
$8 \mathrm{I}$ & $\mathrm{I} 2 / 4$ & Corrections and additions \\
84 & $\mathrm{II} / \mathrm{I}$ & number of bars: 30 \\
\hline 86 & $\mathrm{I2} / 3$ & number of bars: 40 \\
\hline 89 & third note $\mathrm{h}^{2}$ corrected to $\mathrm{c}^{3}$ \\
\hline 89 & (flute)/4
\end{tabular}




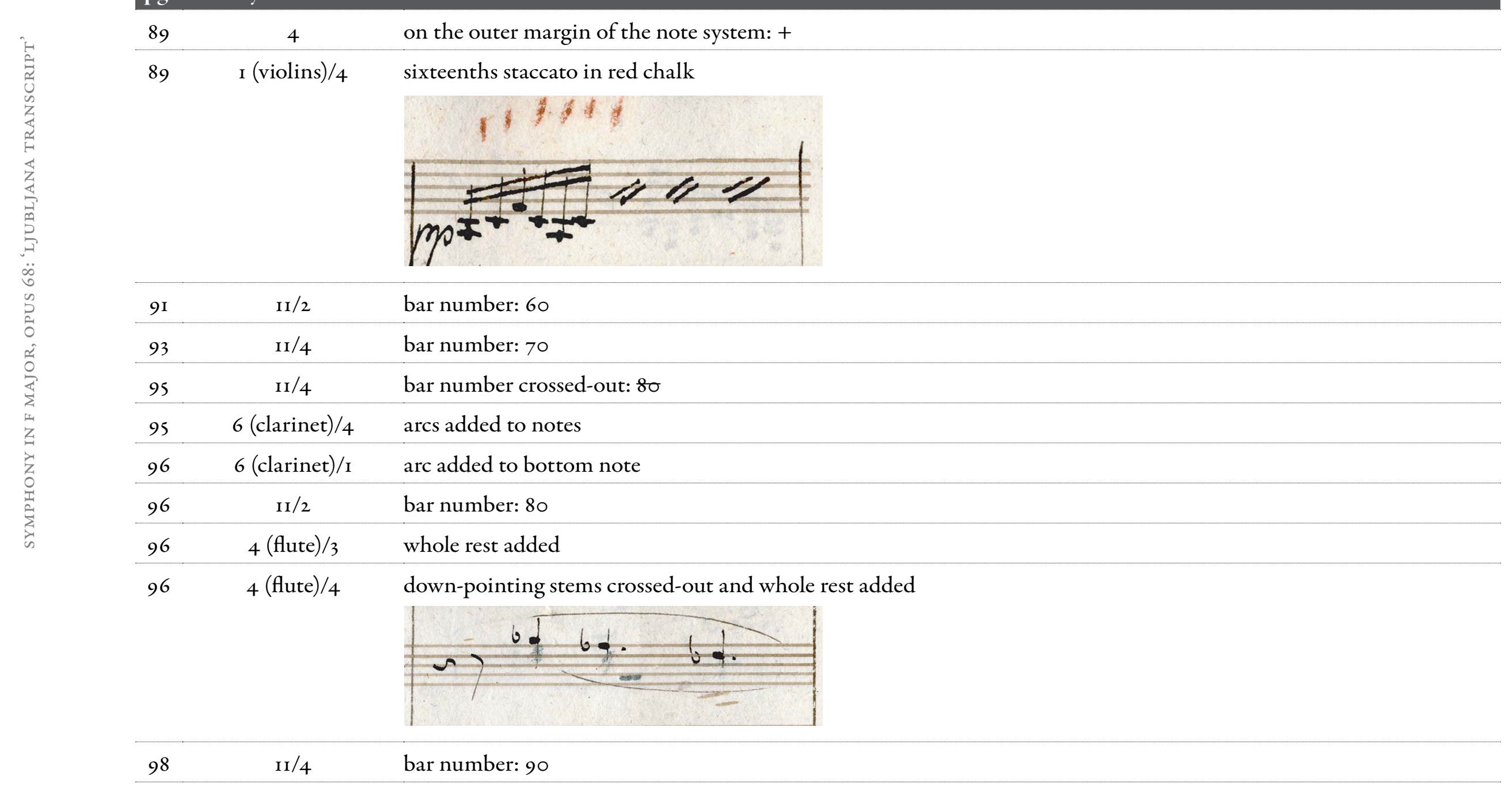




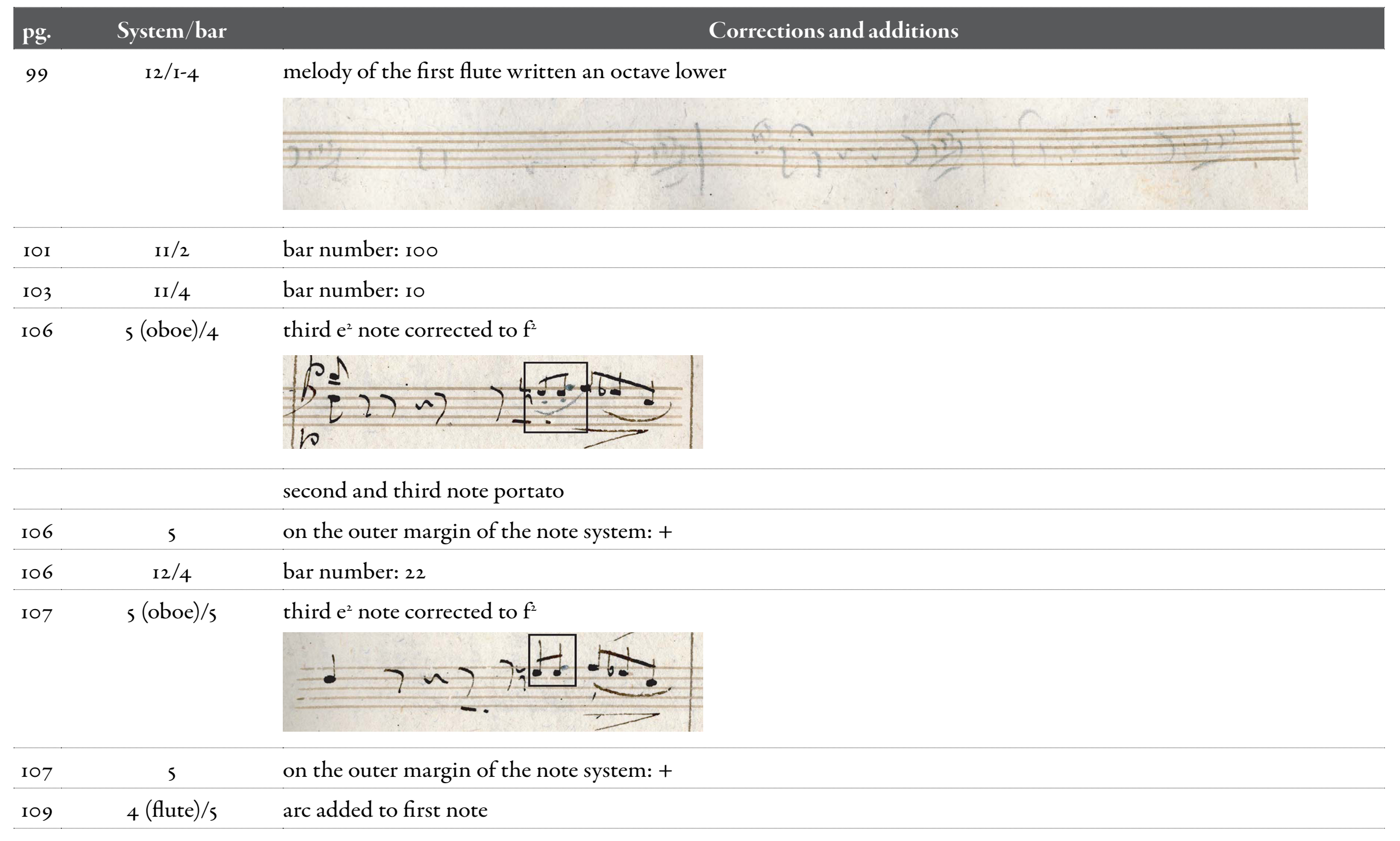


I85 above the stave, left written-in: quasi allegro

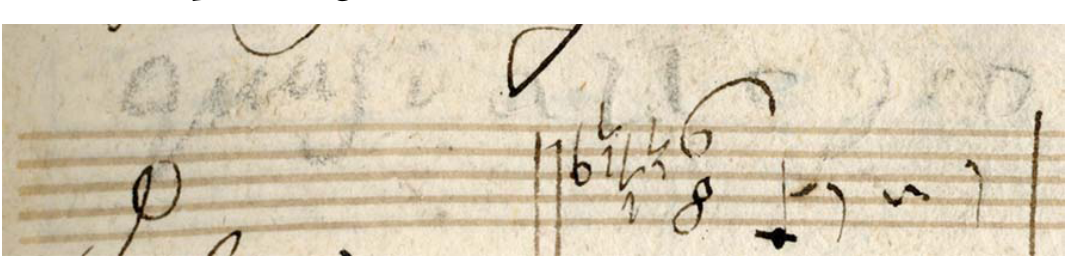

I85 I2 (cello) $/ 5-6$ arcs added to two notes, pencil ${ }^{14}$

\section{Other corrections and additions}

\begin{tabular}{|c|c|c|}
\hline pg. & System/bar & Corrections and additions \\
\hline 2 & title & word Rückunft to Ankunft, ink \\
\hline 29 & $\mathrm{I}($ violins $) / 4$ & sharp added to the fourth note, ink \\
\hline 34 & 7 (bassoon)/r & sharp added to the upper note, lower note sharp crossed-out, ink \\
\hline 67 & Io $($ cello $) / 4$ & arc added to last note, ink \\
\hline 83 & 6 (clarinet)/4 & sharp added to the first lower note, ink \\
\hline 86 & 6 (clarinet) $/ 3$ & written above the first two notes: $\mathrm{g}$, ink \\
\hline III & title & word Zusammensein to Zusammenseyn, ink \\
\hline IIs & I $($ violin $) / 5$ & second $\mathrm{f}^{\mathrm{i}}$ note corrected to $\mathrm{g}^{\mathrm{I}}$, pencil \\
\hline 160 & II/IO & written: $\Theta$, pencil \\
\hline
\end{tabular}


Apart from the title, there are around ten of Beethoven's handwritten corrections and additions in pencil in the second transcript of the score. In the second movement, he changed the instrumentation of the bass line in a way that the playing of the cellos' part was limited to two soloists, while the rest play together with the contrabasses. He did not note the change in the autograph, but communicated it to the publisher on 28 March 1809 in a letter, to which he enclosed a correction list that is unfortunately lost today. ${ }^{15}$ The instruction was added in the cello part as a footnote at the bottom of the page (Due Violoncelli Solo ${ }^{m o}$ e II${ }^{d o}$ con Sordino gli Violoncelli Tutti coi Bassi). The bars from 20 to 122 (pages from 8I to I06) were numbered under the score by Beethoven. It is presumed that the numbering refers to the preparation of the lost correction list for the publisher, since there are the most corrections within these bars. ${ }^{16}$ In the flute and oboe parts, he corrected a note in four places and added a sign for articulation. The staccato markings in the violin part on page 89 are the only addition in red colour, assumed to have been added by the composer in the rehearsals before the concert. ${ }^{17} \mathrm{On}$ page 99, there is a sketched warning to the copyist under the score for $\mathrm{I}^{\mathrm{st}}$ flute. This is a manner of annotation of ideas similar to the one found in the autograph. Beside the corrections in the notes, Beethoven changed the initial tempo marking in the second and the fifth movement.

Although Beethoven's corrections in the score are entered in pencil, not all the additions in pencil are Beethoven's. At the end of the third movement (pg. 160) under the staves, written-in is a ' $\Theta$ ' sign, the meaning of which cannot be determined from the score. In four movements, there are orientational letters or letters 'for practice' written-in ( $\mathrm{I}^{\mathrm{st}}$ movement: $\mathrm{B}-\mathrm{G}, 2^{\text {nd }}$ movement: $\mathrm{B}-\mathrm{F}, 4^{\text {th }}$ movement: $\mathrm{B}-\mathrm{C}, 5^{\text {th }}$ movement:

I5 '... bey Andante in derselbigen Sinf. Ist noch anzumerken in der Baßstimme: gleich anfangs: due Violoncello Solo Imo e 2 do con Sordino gli Violoncelli tutti coi Bassi. Sieghard Brandenburg, ed., Ludwig van Beethoven - Briefwechsel Gesamtausgabe, 2 (München: G. Henle, 1996), 53-4.

I6 Klemenčič, 'Šesta simfonija Ludwiga,' I22; Dufner, 'Kritischer Bericht,' 278.

17 Del Mar, Ludwig van Beethoven, 39 .
$\mathrm{D}-\mathrm{G})$. Corrections of more or less obvious mistakes in ink in a brighter brown ink can also be observed.

The copyist corrected his mistakes in a genuinely special way. So that he would not have to put down the dipped pen each time, he marked the spot with an error on the page margin with a short slash, and corrected it later. Traces of erasing are visible in the score, as well as unmarked corrected spots on the margin of a line (e.g., pg. 6I). The first slash appears on page 5 , and there are 45 altogether in the four movements.

The fourth movement of the symphony is not an original copy by Klumpar. It has been established that it was written out after the original publishing of the parts. ${ }^{18}$ Although the number of pages in the copy matches the last denoted page in Beethoven's autograph, the disposition of bars by pages is different. The sequence of parts in the score is different as well. In the autograph, the piccolo is set under the flutes part, and the part of trombones is placed at the bottom of the score. In the transcripts, the parts of all four instruments that are not played in the first two movements are inserted between the parts of horns and cellos, in the following sequence: piccolo, trombones, trumpets, and timpani. Likewise, in the transcript, the movement is titled Gewitter, Sturm and not Donner, Sturm as is written in the autograph. In the trumpet part, unlike the naming in the original, and in other movements of the transcript (clarini), it says Trompe. The copyist had made mistakes several times in his work and simply crossed-out the bars (str. 163), correcting them without marking the line with an error, or even pasted them over (str. 165 in 168 ).

Because the book block was clipped into the margin, the top edge alignment dropped down to the written record. In numerous pages, top parts of the arcs have been cut-off, ${ }^{19}$ and the cuts have also damaged the tempo markings, and foremost the titles of movements. Continued below, partially or completely cut-off words are reconstructed comparatively with the autograph and the first transcript of the score. Unfor-

I8 Kojima, 'Probleme im Notentext der Pastoralsymphonie,' 234; Dufner, 'Kritischer Bericht,' 277.

19 Damaged are the pages 18, 54, 115, 193-195, 212, 216-217, 219, 224, 226 
tunately, the latter was also substantially damaged on binding, and additionally with water damage.

$I^{\text {st }}$ movement

\begin{tabular}{|c|c|c|}
\hline pg & Visible and partially cut-off text & Reconstructed text \\
\hline 2 & Allõ ma non troppo & All[egr]o ma non troppo \\
\hline & $\begin{array}{l}\text { Angenehme heitre Empfindungen } \\
\text { welche bey der Ankunft auf dem / } \\
\text { Lande im Menschen erwachen }\end{array}$ & $\begin{array}{l}\text { Angenehme heitre Empfindungen } \\
\text { welche bey der Ankunft auf dem } \\
\text { Lande im Menschen erwachen }\end{array}$ \\
\hline
\end{tabular}

$2^{\text {nd }}$ movement

\begin{tabular}{|c|c|}
\hline Visible text & Reconstructed text \\
\hline $77[\ldots]$ & [Andante molto moto] \\
\hline fcene [crossed-out] am Bach & Scene am Bach \\
\hline \multicolumn{2}{|l|}{$3^{r d}$ movement } \\
\hline Visible text & Reconstructed text \\
\hline II Allo: & All[egro]: \\
\hline Lustiges Zusammenseyn der [...] & $\begin{array}{l}\text { Lustiges Zusammenseyn } \\
\text { der [Landleute] }\end{array}$ \\
\hline 129 a tempo & a tempo [allegro] \\
\hline I57 a tempo allo & a tempo all $[\mathrm{egr}]_{\mathrm{o}}$ \\
\hline
\end{tabular}

pg. Visible text

Reconstructed text

I6I $G[\ldots]$ $G[$ ewitter, Sturm $]$ $s^{\text {th }}$ movement

\begin{tabular}{lll} 
pg. & \multicolumn{1}{c}{ Visible text } & \multicolumn{1}{c}{ Reconstructed text } \\
I85 & {$[\ldots]$} & {$[$ Hirtengesang] } \\
\hline$[\ldots]$ & {$[\text { Allegretto }]^{20}$} \\
& {$[\ldots]$ / nach dem Sturm } & {$[$ Wobltätige, mit Dank an die } \\
& $\begin{array}{l}\text { Gottheit verbundene Gefühle }] \\
\text { nach dem Sturm }\end{array}$
\end{tabular}

Let us return to Keesbacher and his description of the score from I862. Beethoven's writing was, alongside the title written in red chalk, identified in two more correction entries in pencil. He quoted the note on the bottom margin of the first page of the second movement and a postscript 'quasi allegro' under the tempo mark 'Allegretto' at the start of the fifth movement. ${ }^{21}$ The tempo mark and the title of fifth movement cited by Keesbacher are no longer visible today, as they were nearly entirely cut-off in binding.

So Keesbacher did not have before him the score in today's binding. It is also unusual that he named the title page as cover in his description. ${ }^{22}$

20 From bottom edge of the writing, Del Mar made out the words Hirtengesang Allegretto (Del Mar, Ludwig van Beethoven, $\mathrm{xx}$ ).

2 I 'Diese Partitur zeigt an mehreren Stellen Korrekturen in Bleistift ausgeführt. Zwei davon scheinen von Beethovens Hand zu stammen; leider ist das Blei schon verwischt, das an eine endgültige Entscheidung über die Schriftzüge schwer zu denken ist. In der Szene am Bach, wo der I2/8 Takt begint (aus b dur) stehen die Worte: "Violoncelli tutti con Basso". Namentlich das B erinnert an die Beethoven'sche Schreibart. Ferner die Tempo-Vorzeichnung beim Beginne des Hirtengesanges (in $f$, 6/8 Takt 'Allegretto' ist von derselben Hand in Bleistift näher bestimmt mit den nachfolgenden Worten: 'quasi allegro'. Ein direkter Beweis der Uebersendung liegt nicht vor.' Keesbacher, 'Die philharmonische Gesellschaft in Laibach,' 170.

22 Keesbacher says: 'Das gedachte Exemplar ist eine (nicht von ihm) geschriebene Partitur. Auf dem Umschlage steht mit Rothstift und zwar unverkennbar in seinen Charakteren geschrieben: "Sinfonie pastorale", darunter stehen mit 
Cut as well are orientation letters above the note record, and it is obvious that they were entered in the score before the last binding.

Marking the five movements of the symphony with three sets of letters and the composition's partition into three movements corresponds with statements in the otherwise incompletely preserved programmes of philharmonic concerts (academies) from I822 to I831. Last three movements which Beethoven connected using the mark attacca were played as a unified $3^{\text {rd }}$ movement. In two programmes from I 823 and 1825 , the title Pastoral Sinfonie oder Erinnerung an das Landleben and programme titles of movements are mentioned in a polished version of the first edition of orchestral parts from $1809 .{ }^{23}$ The information allows for the conclusion that the Ljubljana Philharmonic had already played from these in 1818 , when the symphony was first documented to have been performed in Ljubljana, ${ }^{24}$ as well as that these have later served as template for writing out the parts with the record of the $4^{\text {th }}$ movement, which was missing from the score.

Tinte von anderer Hand geschrieben die Worte: "Beethovens Hand mit Röthel'” Keesbacher, 'Die philharmonische Gesellschaft in Laibach,' 170.

23 Titles of movements in the concert sheet of 23. 5./May I823 are: 'Erster Satz: Erwachen heiterer Empfindungen bey der Ankunft auf dem Lande, Zweyter Satz: Scene am Bach, Dritter Satz: Lustiges Zusammentreffen der Landleute - Gewitter, Sturm - Hirtengesang. Frohe und dankbare Gefüble nach dem Sturme.' Arhiv Filharmonične družbe, Koncertni sporedi, Narodna in univerzitetna knjižnica, Ljubljana, Glasbena zbirka. Comp. first violin part in the first edition from I809. Beethoven, Ludwig van, Sinfonie Pastorale pour 2 Violons, 2 Violes, Violoncelle et Contre-Violon, 2 Flûtes, petite Flûte, 2 Hautbois, 2 Clarinettes, 2 Bassons, 2 Cors, 2 Trompettes, Timbales et 2 Trompes, parti. Leipzig: Breitkopf \& Härtel., [1809], plate no. I337. Accessible at: Beethoven-Haus Bonn, Digitales Archiv, www.beethoven.de/de/digitales-archiv.

24 Cited in the literature is the date of first performance 28 February 1818 , summarised after the concert programme from the archive of Philharmonic Society that is lost today. The information was recorded by Keesbacher as well in the manuscript chronicle of the Philharmonic Society (Keesbacher, Die philharmonische Gesellschaft in Laibach, 108). Also confirming that the pastoral symphony was played in academy of the Philharmonic Society (die herrliche Pastoralsymphonie) before April I8I9 is the report 'Aus der Tagsgeschichte von Laibach,' Illyrisches Blatt, April 30, 1819, 70.
The Philharmonic Society has abundantly stamped the score but, unfortunately, has not recorded its receipt. For a while, it served practical performing purposes, and it seems that it was given no special attention until Keesbacher's arrival. If, all those two hundred years ago upon Beethoven's election as an honorary member, the receipt of his letter was immediately announced in the newspaper, the silence on suppositional receipt of such magnificent gift is that much more inconceivable. ${ }^{25}$

The NUK Music collection acquired the score from the Academy of Music in Ljubljana on 28 June 1955. In post-war years, the academy operated in the nationalised building of Glasbena matica and also had its rich library at its disposal. Three decades earlier, the music collection of the Philharmonic Society, becoming a branch of Glasbena matica after World War I, met with a similar fate. The document of receipt states under point 23: 'Beethoven, Symphonie pastorale, orchestra score, old transcript ${ }^{26}{ }^{26}$ It was entered in the inventory book of the collection for the year 1955 under the number $1765 .^{27}$

25 'Ludwig van Beethoven', Illyrisches Blatt, May 28, 1819, 85.

26 The document of receipt was signed for NUK by Ludvik Zepič. In the business report for the year 1955 for the NUK Musical department it is registered that 'NUK ceded due to exchange, from its FZC-stock to the Academy of Music in Ljubljana, around 800 second-hand, mostly German educationa theoretical musical editions, and received for this a material much more important for NUK, namely musical editions from the precious archive of the Ljubljana Glasbena matica, that is, over I0oo Slovenian manuscript compositions of older Slovenian composers, and more extensive folders of historically significant society files of the former Ljubljana Philharmonic Society. All this material was being kept after the year of liberation (1945) by the Academy of material was being kept after the year of liberation (1945) by the
Music in its library, and has now ceded it in exchange to NUK?

27 Date of receipt: 28 . VI. 1955, date of entry: 29. VI., title of work: Beethoven L. Symphonie pastorale, orchestr. score, org. trans., manner of purchase: Z, purveyor: Academy of Music, Ljubljana, Notes: Archive of Glasbena matica in Ljubljana. From work statistic for [the month of] June 1955, it is evident that the catalogue ticket for alphabetical-nominal catalogue was made on 29. 6./ June 1955. 